\title{
Beach Carrying Capacity Analysis for Sustainable Tourism Development in the South West Coast of India
}

\author{
Brilliant Rajan ${ }^{1}$, Vincy Mary Varghese ${ }^{2}$ and \\ Anakkathil Purushothaman Pradeepkumar ${ }^{3}$ \\ ${ }^{1}$ Assistant Professor, PG Department of Environmental Science, St. John's College, Anchal \\ ${ }^{2}$ School of Environmental Sciences, Mahatma Gandhi University, Kottayam \\ ${ }^{3}$ Reader, Department of Geology, University of Kerala, Kariavattom
}

cross $^{\text {ref }}$ http://dx.doi.org/10.5755/j01.erem.63.1.2648

(received in October, 2012, accepted in March, 2013)

\begin{abstract}
The rapid growth of coastal tourism that has been seen in the last 10 years is frequently described as one of the major reasons for the development of these areas and also is responsible for many current coastal problems. The beaches perform, in this context, a fundamental role, where the issues related to planning and management are increasingly more important when it comes to an implementation of a sustainable development philosophy. In Kerala, where coastal tourism plays a major part of the state's economy, the management of beaches is crucial for maintaining their quality and therefore continuing to attract tourists. Since the 1990s, with the application of Coastal Zone Management Plans to the whole Kerala coast, beach plans are now required. The concept of capacity has received considerable attention as a result of increasing anthropogenic pressure in certain natural environments. Much consideration has recently been given to an increase in coastal population, with the implication that the carrying capacity of the world's coast is finite, and such consideration forms part of several coastal management initiatives. Tourism is the world's largest industry, which accounts for more than $10 \%$ of total employment, $11 \%$ of global GDP, and total tourist trips are predicted to increase to 1.6 billion by 2020 . The ecosystems, typically stressed by development activity along the Indian coastal areas, are particularly vulnerable to socio-economic driving forces. The planning and management of coastal tourism can be improved through more careful understanding of social and ecological systems and their linkages, with a view to ensure a development that lasts, not only for tourism but also for the host destination. The present study gives a comprehensive idea on both sustainability of coastal areas and a prerequisite for the carrying capacity based development in tourism destinations.
\end{abstract}

Keywords: coastal tourism; beach carrying capacity; coastal management; sustainable development.

\section{Introduction}

'Sustainable tourism development meets the needs of present tourists and host regions while protecting and enhancing opportunity for the future. It is envisaged as leading to management of all resources in such a way that economic, social and aesthetic needs can be fulfilled while maintaining cultural integrity, essential ecological processes and biological diversity and life support systems' (WTO 2004).

Environmental management involves the management of all components of the bio-physical environment for sustainable development; the carrying capacity assessment is considered as an effective management tool to reduce negative environmental impacts. Unsustainable management of natural resources is now considered as a global issue rather than a regional one. The concept of tourism carrying capacity is based on the general statement that any form of development within the carrying capacity of ecosystem means sustainable utilization of tourist resources and development of ecosystem. When an area is used beyond its capacity, the quality of natural resources changes and gets destroyed. The increased inflow of either local or foreign tourists 
beyond the carrying capacity of the area may deteriorate the area due to increase in luxury hotels, shopping centres and fun plaza in ecotourism regions (Lindberg et al. 1997). Ecotourism has every threat to wipe out the plant and wildlife species, and further it may lead to replace the entire ecosystem into an artificial landscape (Gossling 1999). There is a need to preserve and protect the fragile natural sites, wildlife and ecosystem, and at the same time there is a need to educate people and to create employment opportunities in order to fight poverty and misery (Bill 2001). One way to deal with this problem is to enumerate the carrying capacity. Any tourism beyond the acceptable carrying capacity should be strictly prohibited, the carrying capacity can be in relation to environment, social and economical (Trakolis 2003). An environmental approach defines it as the ability of natural resources and ecosystem to support the tourism development.

The lack of management and planning has resulted in the destruction and degradation of several resort areas and scenic attractions, affected fragile ecosystems and the environment, and created adverse impacts on host's cultures. Because of such effects tourism has been criticised and charged with destroying the very resources on which it is founded. The need for the proper management of tourism is thus essential for its development.

Varkala, a coastal town in Thiruvananthapuram district is a fast developing tourism destination, which is increasingly attracting many Indian and foreign tourists. The areal extent of the study area falls within $8^{\circ} 71^{\prime}$ to $8^{\circ} 78^{\prime} \mathrm{N}$ latitude $76^{\circ} 67^{\prime}$ to $76^{\circ} 72^{\prime} \mathrm{E}$ longitude. It covers a total area of $29.62 \mathrm{~km}^{2}$. The study area experiences a moderate climate, just as in other parts of the state, and is in general free from extremes of hot and cold. Varkala has witnessed great developments in its infrastructure since the advent of the tourism industry. There has been a boom in the hospitality sector in Varkala in the recent years owing to the popularity of its beaches and various religious spots in the area. Lovely coconut palm areas and the gentle wind from the sea attract many nature tourists. Calm sea in the tourist seasons gives a good opportunity to enjoy the sea and do sun bathing in Varkala. Calm back waters (Kilimukkam and Nadayara Kayal) are fringed by coconut palms and the boating in this setting are really enjoyable. Roads with sparse traffic and the whole range of accommodation and food, friendly local people and fishermen, good road and rail connections, fresh air etc. attract tourists. The beach carrying capacity studies in the area were carried out during the period of 2004 to 2011 at different seasons.

\section{Methodology}

Carrying capacity is 'the maximum level of visitor use an area can accommodate with high levels of satisfaction for visitors and few negative impacts on resources' (McNeely and Thorsell 1987). The
World Tourism Organisation (WTO) defines the concept of carrying capacity as follows: "The maximum number of people that may visit a tourist destination at the same time, without causing destruction of the physical, economic and sociocultural environment and an unacceptable decrease in the quality of the visitors' satisfaction" (cited in PAP/RAC 1997).

Hunter (1995) gives a more precise definition by distinguishing four different types of carrying capacity:

"Physical carrying capacity - the limit of a site beyond which wear and tear will start taking place or environmental problems will arise.

Psychological (or perceptual) carrying capacity - the lowest degree of enjoyment tourists are prepared to accept before they start seeking alternative destinations.

Social carrying capacity - the level of tolerance of the host population for the presence and behaviour of tourists in the destination area, and/or the degree of crowding users (tourists) are prepared to accept by others (other tourists).

Economic carrying capacity - the ability to absorb tourism activities without displacing or disrupting desirable local activities."

Papageorgiou and Brotherton (1999) underline what they think the central point of the concept of carrying capacity is: "In a recreational context, central to all definitions of carrying capacity is the idea of maintenance of the integrity of the resourcebase and the provision of a high-quality recreation experience to users." To calculate this figure it is necessary to establish maximum use estimates. In practice, many planners rely on defining what constitutes a 'tolerable level' of visitation which can be sustained over time. The maximum sustainable capacity of an area requires the careful planning of geographically separated access points and placement of tourist's facilities to avoid excessive contacts between different groups visiting the area at the same time. Issues of seasonality need to be incorporated within both animal and human communities. Much attention to the problems of estimating carrying capacity has been given by the WTO (WTO/UNEP 1992) who recommends a formula (Boullon 1985) for estimating tourist carrying capacity as:

$$
\text { carryingcapacity }=\frac{\text { areausedbyourists }}{\text { average individual standard }}
$$

The denominator is usually expressed as persons/metre ${ }^{2}$, which is carefully defined for each case by evaluating psychological and ecological capacity. According to Shackley (1996), in order to determine environmental factors it is necessary to know the size of the area and usable space, fragility of the environment, wildlife resources and topography and vegetation cover. According to the WTO (1988), a beach should not have more than 1000 people per hectare. Therefore, each beach tourist should have at least $10 \mathrm{~m}^{2}$ of the beach area. A reconnaissance 
survey was carried out to collect the ground information. The GIS database generated from the topographic sheets was further updated with the latest changes in the study areas. Ground truth was collected during the field visit with the help of satellite image, SOI topographical sheets, GPS and magnetic compass. The image elements were correlated with the ground truth and the interpretation key was developed. The tonal variation representing different classes was marked on the hard copy image. The entries were made in the field description form at each of the sample point. Base maps including drainage, roads, settlement and study area boundary were extracted from the SOI topographical sheet (1969) no $58 \mathrm{D} / 14$ and $58 \mathrm{D} / 9$. Delineation of a beach map was prepared using map info version 5 and 7.

\section{Results and Discussion}

It was with concern and recognition of the need to understand coastal systems in terms of developing sustainable tourism that the concept of carrying capacity arose in the context of tourist areas; the intention being to avoid the saturation levels that both put natural systems at risk and disturbed the users' quality of enjoyment. In the case of beaches, their planning and management will depend on innumerable factors, but without doubt, what should be a condition in terms of utilization is the carrying capacity. The importance of this indicator is fundamental in the following: as the recreational use of a beach intensifies, the quality of enjoyment for the users can diminish. Beaches are highly valuable tourist resources; therefore determination of their carrying capacity is an essential factor for their sensible use and management.

\subsection{Available beaches and beach areas for tourism}

Beaches are the most attractive tourism destinations worldwide. Beach formation is a seasonal phenomenon, thus the beach formation season is depicted as the peak tourism season, which is September to March in Varkala area.

There are nine pocket beaches in Varkala which are named from south to north as:

1. Chilakkur beach. The average beach area in Chilakkur in the peak tourism season is 8750 sq. $\mathrm{m}$. and 1500 sq. m. in the off-season. The Chilakkur area has some fishermen's colony and groins to prevent the attack of the sea. Compared to other areas the sea in Chilakkur beach is rough, especially in an off-season period. But in a peak season, the beach is beautiful with a panoramic view of the sand and the view of fishermen's boats including country boats.

2. Enikkal beach. Enikkal beach is a small pocket beach in a peak tourism season. The average beach area is 1250 sq. m., but in an off- season it reduces to 500 sq. $\mathrm{m}$. There is a fresh water spring flowing from the cliffs into Enikal beach. The fresh water spring enables tourists to have a fresh water bath after sea water bath. The beautiful view of the sea from above the cliff of Enikkal beach is an unforgettable experience to tourists. A stream flowing in this area carries the waste water from Varkala town and nearby houses onto the beach.

3. Papanasam beach. The most popular and elongated beach area in Varkala is Papanasam beach. The available beach area in a peak tourism season is $12250 \mathrm{sq}$. $\mathrm{m}$. and in an offseason 3000 sq. m. The Papanasam area has the beach throughout the season. The area is particularly important for religious rituals like 'Vavubali' and the centuries old Janardhana swami temple. There is a good number of resorts concentrated around the beach. Two streams carry the waste water from hotels and resort into the beach and form the major environmental problem on the beach.

4. Black sand beach. It is a very small pocket beach with black sand, situated north of Papanasam beach. The beach is available only in a peak season and is located above the seawall. The beach area is only 950 sq. m. but in an offseason it is reduced to $50 \mathrm{sq}$. m. or even absent.

5. Thiruvambadi beach. The beach is also a pocket beach formed during the peak tourism season. The available beach area in a peak tourism season is only 1300 sq. m., but in the off-season it reduces to 600 sq. $\mathrm{m}$. The sea is very calm during the peak tourism season and very rough in off season.

6. Odayam. It is a very small pocket beach with the available beach area of 1125 sq. m., in an offseason it being only 300 sq. m.; a few resorts are also found around the beach.

7. Manthara beach. It is a very small pocket beach and the available beach area during the peak tourism season is 500 sq. m., which completely disappears in the off-season.

8. Vettakada beach. The beach in Edava panchayath has an available beach area of 450 sq. m. in the peak season and only 250 sq. m. in the off-season.

9. Kappil beach. The Kappil region is one of the most beautiful beach areas partitioned by a sand bar with the sea on one side and back water on the other side. The sand bar extends for 10000 $\mathrm{km}^{2}$ in the peak season and for $3500 \mathrm{~km}^{2}$ in the off-season.

\subsection{Total beach area}

The total beach area in a peak tourism season is $100,000-135,950 \mathrm{~m}^{2}$. The average beach area is $117,725 \mathrm{~m}^{2}$, but the available beach area is $29,300 \mathrm{~m}^{2}$. The total beach area in an off-season is between $60,850-87,300 \mathrm{~m}^{2}$ and the available beach area is $9,650 \mathrm{~m}^{2}$. 
Beach area-Varkala

\begin{tabular}{|c|c|c|c|c|c|c|c|}
\hline $\begin{array}{l}\text { SI. } \\
\text { No. }\end{array}$ & Name of Beach & $\begin{array}{c}\text { Beach area } \\
\text { in peak } \\
\text { season }(\mathrm{Sq} . \\
\text { m) }\end{array}$ & $\begin{array}{c}\text { Average } \\
\text { beach area } \\
\text { in peak } \\
\text { season (Sq. } \\
\text { m.) }\end{array}$ & $\begin{array}{l}\text { Available } \\
\text { beach } \\
\text { area in } \\
\text { peak } \\
\text { season } \\
\text { (Sq. m.) }\end{array}$ & $\begin{array}{l}\text { Beach area in } \\
\text { off- season } \\
\text { (Sq. m.) }\end{array}$ & $\begin{array}{c}\text { Average } \\
\text { beach area in } \\
\text { off- season } \\
\text { (Sq. } \text { m.) }\end{array}$ & $\begin{array}{l}\text { Available } \\
\text { beach } \\
\text { area in } \\
\text { off-season } \\
\text { (Sq. m.) }\end{array}$ \\
\hline 1 & Chilakkur beach & $5000-12500$ & 8750 & 4000 & $3500-8000$ & 5750 & 1500 \\
\hline 2 & Eanikkal beach & $500-2000$ & 1250 & 1250 & $300-1000$ & 650 & 500 \\
\hline 3 & Papanasam beach & $10000-15000$ & 12250 & 10000 & $6000-10000$ & 8000 & 3000 \\
\hline 4 & Black sand beach & $700-1200$ & 950 & 950 & $0-100$ & 50 & - \\
\hline 5 & $\begin{array}{l}\text { Thiruvambadi } \\
\text { beach }\end{array}$ & $1600-1800$ & 1700 & 1300 & $500-1250$ & 875 & 600 \\
\hline 6 & Odayam beach & $1000-1250$ & 1125 & 850 & $250-750$ & 500 & 300 \\
\hline 7 & Manthra beach & $500-1000$ & 750 & 500 & $0-400$ & 200 & - \\
\hline 8 & Vettakkada beach & $700-1200$ & 950 & 450 & $300-800$ & 550 & 250 \\
\hline 9 & Kappil sand bar & $\begin{array}{l}80000- \\
100000\end{array}$ & 90000 & 10000 & $50000-65000$ & 57500 & 3500 \\
\hline \multicolumn{2}{|r|}{ Total area (Sq. m.) } & $\begin{array}{c}100000- \\
135950\end{array}$ & 117725 & 29300 & $60850-87300$ & 74075 & 9650 \\
\hline
\end{tabular}

\subsection{Carrying capacity of Varkala beach}

The available beach area in a peak tourism season is $29,300 \mathrm{~m}^{2}$. Thus, the optimum number of tourists in a peak tourism season is 2,930. The available beach area in an off-season is only $9,650 \mathrm{~m}^{2}$ and the optimum number of tourists in off seasons is calculated as 965 . The sea is comparatively rough and a fewer number of pocket beaches in an off-season prevents the tourist enjoyment there. The study area Varkala is at the brim of carrying capacity, hence, further tourism activities should be strictly regulated there.

The measurement of beach areas for physical carrying capacity evaluation was performed by da Silva (2002) in Sines coast of Portugal. The physical carrying capacity of the Varkala area indicates that about 2930 tourists can be accommodated at a time in the peak tourism season. The number of tourist arrivals varies from hundreds to thousands in a peak tourism season per day. The total bed capacity of Varkala is found to be 1969; the rooms are mainly meant for foreign tourists and tourists from other places. But quite a number of local tourists visit Varkala each day, and they also need the beach area for recreation. According to Silva et al. (2007) beaches are classified as below:

Type 1 - urban beach with intensive use;

Type 2 - non-urban beach with intensive use;

Type 3 - infra-structured beach with conditional use; Type 4 - non infra-structured Beach with conditional use;

Type 5 - restricted use beach;

Type 6 - prohibited use beach.

Table 2.

Carrying capacity of beaches in Varkala

\begin{tabular}{||l|l|c|c|c|c||}
\hline SI. No & \multicolumn{1}{|c|}{ Name of Beach } & $\begin{array}{c}\text { Available beach area } \\
\text { in peak season (Sq. } \\
\text { m.) }\end{array}$ & $\begin{array}{c}\text { Carrying capacity of } \\
\text { beaches in peak } \\
\text { season (In. nos) }\end{array}$ & $\begin{array}{c}\text { Available beach } \\
\text { area in off season } \\
\text { (Sq. } \mathbf{~ m . )}\end{array}$ & $\begin{array}{c}\text { Carrying capacity of } \\
\text { beaches in off-season } \\
\text { (In. nos) }\end{array}$ \\
\hline 1 & Chilakkur beach & 4000 & 400 & 1500 & 150 \\
\hline 2 & Eanikkal beach & 1250 & 125 & 500 & 50 \\
\hline 3 & Papanasam beach & 10000 & 1000 & 3000 & 300 \\
\hline 4 & Black sand beach & 950 & 95 & - & - \\
\hline 5 & Thiruvambadi beach & 1300 & 130 & 600 & 30 \\
\hline 6 & Odayam beach & 850 & 85 & 300 & - \\
\hline 7 & Manthra beach & 500 & 50 & - & 25 \\
\hline 8 & Vettakkada beach & 450 & 45 & 250 & 350 \\
\hline 9 & Kappil sand bar & 10000 & 1000 & 3500 & $\mathbf{9 6 5}$ \\
\hline
\end{tabular}

For each category there are different criteria associated with the measurement of the carrying capacity of the beach, with the first ones, type 1 and 2 associated to a more heavy demand and thus supporting higher densities. The other types are the ones that present some environmental sensitivity, therefore they must be carefully managed. The last one, type 6 , is the case of beaches that for some 
reason are without safety conditions for beach users. The study points out that Varkala comes under type 2 category of beaches, i.e. - Non-Urban Beach with intensive use. Johnson and Thomas (1996) argue that the present interest in tourism capacity is linked to the growth in tourism combined with increasing awareness of environmental issues. It helps the management to plan a strategy, which reflects a predetermined set of environmentally and socially desirable conditions (Williams and Gill 1991).

Considering the tourism industry, the need to adopt a 'sustainable' approach is exacerbated by its fragility and sensitivity to change, its multi-sector nature, and its marked dependence on the quality of the host environment and communities; 'tourism which degrades any elements of host communities and nations threatens its own future' (Manning 1999). Managing of existing destinations is a key element in this research, the need to redefine tourism development in the existing destinations on a more sustainable basis. Recreational carrying capacity is 'the amount of development and activity a body of water can handle before it starts to deteriorate,' as defined by Jacquie Colburn of the New Hampshire Department of Environmental Services (Doshi 2006).

Tourism activities began in time immemorial, early travels were mainly for sustaining livelihood activities, but the modern travel and tourism are mainly for pleasure and recreation; this results in exploitation of newer and newer areas without any concern for nature. The over exploitation of the tourism areas can result in pollution and destruction of natural flora and fauna, the natural beauty of the area and adverse social, economic and cultural impacts on local population. Tourism development based on carrying capacity and sustainable development becomes relevant in this scenario for proper management of natural resources, thus the present as well as future generations may enjoy nature's beauty and thereby enhance tourist flows and revenues.

\section{Conclusions and recommendations}

Defining the carrying capacity of a beach is undoubtedly a complex issue, where consensus is hard to be achieved. This simple case study aimed at identifying some of the aspects, that condition this evaluation more than define the carrying capacity of the beach per se. Taking into consideration the factors such as beach topography, location of access points, parking availability, or the perception by users could actually be more important than the total sand area utilisable for recreational purposes. Since the distribution is not homogeneous all over the beach, the use of a standard density application is not appropriate.

The carrying capacity of a beach cannot be expressed as a fixed and rigid value; on the contrary, as defined by other authors (De Ruyk et al. 1997), it should oscillate between two tolerable thresholds, allowing the management of the concept in an integrated, flexible and sustained way.

The coastal tourism destination Varkala is at the brim of the carrying capacity, further construction activities should be totally prevented in the area. The beach areas have been delineated using remote sensing and GIS techniques.

The major recommendations drawn on the base of the study are:

1) Tourism development should be within the carrying capacity.

2) The number of visitors to the area should be regulated.

3) Strict implementation of CRZ (Coastal Regulation Zone) and gain access to the sea.

\section{References}

BILL, L. W. Sustainable tourism - challenges and opportunities for Hawaii. Journal of Sustainable Tourism, 2001, Vol. 9, No. 1. pp. 1-6.

BOULLÓN, R. C. 1985. Planificacion del Espacio Turisico, Editorial Trillas, Mexico. In: McNeely, J. A., Thorsell, J. W., and Ceballos-Lascurain, H. 1992. Guidelines: Development of national parks and protected areas for tourism, WTO, UNEP.

DE RUYCK, M.C., SOARES, A.G. and McLACHLAN, A. 1997. Social Carrying Capacity as a Management Tool for Sandy Beaches. Journal of Coastal Research, Vol. 13, No. 3, 822-830.

DA SILVA, C. P. Beach Carrying Capacity Assessment: How important is it? Journal of Coastal Research, 2002, Special Issue. 36, pp. 190-197.

DOSHI, S. Recreational Carrying Capacity in Lakes: How much is too much? Clean Lakes Program, Office of Water Quality, Indiana Department of Environmental Management, Water Column Summer, C. P. 2006,. Vol.18, No. 2.

GOSSLING, S. Ecotourism: A means to safe guard biodiversity and ecosystem functions. Ecological Economics, 1999, Vol. 29, pp. 303-320. http://dx.doi.org/10.1016/S0921-8009(99)00012-9

HUNTER, C. 1995. Key concepts for tourism and the environment. In: Hunter, C. \& Green H. (eds.). Tourism and the Environment. A sustainable relationship? Routledge, London-New York. p. 52-92.

JOHNSON, P. and Thomas, B. Tourism capacity: a critique. In Briguglio, L. (ed.), Sustainable Tourism in Islands and Small States: Issues and Policies, 1996, pp: 118-136.

LINDBERG K, MCCOOL SF, STANKEY G. Rethinking Carrying Capacity. Annals of Tourism Research, 1997, Vol. 24, No. 2, pp. 461 - 465. http://dx.doi.org/10.1016/S0160-7383(97)80018-7

MANNING, T. Indicators of Tourism Sustainability. Tourism Management, 1999, Vol. 20, pp. 179-181.

MCNEELY, J. A. and THORSELL, J.W. Guidelines for the development of terrestrial and marine national parks for tourism and travel. 1987, IUCN, Gland.

PAP/RAC. 1997. Guidelines for Carrying Capacity Assessment for Tourism in Mediterranean Coastal Areas. Priority Actions Programme Regional Activity Centre, Split. viii $+51 \mathrm{p}$.

RAJU, K., SUCHINDAN, G. K., BRILLIANT, R. Terrain Evaluation for Sustainable Coastal Tourism 
Development of Varkala, Kerala. Indian Cartographer, 2007, pp: 114-119.

SILVA, C. P., ALVES, F. and ROCHA, R. The Management of Beach Carrying Capacity: The case of northern Portugal. Journal of Coastal Research, 2007, SI 50 (Proceedings of the 9th International Coastal Symposium), pp. 135-139. Gold Coast, Australia, ISSN 0749.0208.

SHACKLEY, M. 1996. Wildlife Tourism. International Thomson Business Press, USA.

TRAKOLIS, D. Carrying Capacity- An Old Concept: Significance for the Management of Urban Forest Recreation. New Medit. 2003, Vo. 2, No. 3, pp. 58-64.

WILLIAMS, P. and GILL, A. 1991. Carrying Capacity Management in Tourism Settings: A Tourism Growth Management Process. Centre for Tourism Policy and Research, Simon Fraser University, B. C.

WORLD TOURISM ORGANIZATION. 1998. Guide for Local Authorities on Developing Sustainable Tourism. Madrid: The World Tourism Organization.

WTO/UNEP 1992 Guidelines: Development of national parks and protected area for tourism. Madrid: World Tourism Organization.
Dr. Brilliant Rajan - Ass. Professor, Department of Environmental Science, St. John's College, Anchal

Main research areas: Carrying capacity, environmental management, sustainable development. Address: $\quad$ St. John's College, Anchal Tel.: $\quad 9446917941$

E-mail: $\quad$ brilliantrajan@gmail.com

Vincy Mary Varghese - Research Scholar at Centre for Remote Sensing and GIS, School of Environmental Science, Mahatma Gandhi University. Main research areas: hydrological modelling, GIS, Remote sensing, environmental management, sustainable development.

Address: $\quad$ Kottayam, Kerala- 686560

E-mail: $\quad$ vincybrilliant@gmail.com

Dr. Anakkathil Purushothaman Pradeepkumar Reader at Department of Geology, University of Kerala, Kariavattom.

Main research areas: environmental disaster management, geology, petrology.

E-mail: $\quad$ geo.pradeep@gmail.com 


\title{
Galimybiụ taikyti darnaus turizmo principus Indijos pietvakarių pakrantès paplūdimiuose analizè
}

\author{
Brilliant Rajan', Vincy Mary Varghese'2, \\ Anakkathil Purushothaman Pradeepkumar ${ }^{3}$ \\ ${ }^{1}$ Aplinkos mokslu fakultetas, $\breve{S}$. Jono kolegija, Indija \\ ${ }^{2}$ Aplinkos mokslu mokykla, Mahatma Gandžio universitetas, Indija \\ ${ }^{3}$ Geologijos fakultetas, Keralos universitetas, Indija
}

(gauta 2012 m. spalio mèn., priimta spaudai 2013 m. kovo mèn.)

\begin{abstract}
Pastaruoju dešimtmečiu besiplètojantis priekrančiu turizmas sąlygoja šių zonu plètrą ir dažnai ivvardijamas kaip vienas iš pagrindinių aspektų, lemiančių priekrantės problemas. Paplūdimiai šiose zonose turi didžiausią itaką, todèl, galvojant apie priekrančiu zonų darnią plètrą, ypač svarbiais klausimais tampa paplūdimių planavimas ir valdymas. Keraloje priekrančių turizmas yra svarbus ekonomikos sektorius, todèl paplūdimių valdymas yra esminis veiksnys, leidžiantis palaikyti jų kokybės lygi ir užtikrinti regiono patrauklumą turis-tams. Nuo $1990 \mathrm{~m}$. pradèti taikyti priekrantès zonos valdymo planai visai Keralos priekrantei, todèl ir paplūdimių planai šiuo metu yra privalomi. Ypač svarbus dèmesys skiriamas paplūdimiu talpai, nes taip vertinamas antropogeninès įtakos gamtinei aplinkai lygis. Daug dèmesio skiriama gyventoju daugèjimo priekrančiu zonose analizei, vertinant tai, kad priekrančių zonos talpos pajègumai yra riboti. Todèl reikia valdyti svarbius priekrantės zonos aspektus. Turizmas yra viena didžiausių pasaulio verslo šaku, kur dirba 10 proc. darbuotojų, sudarančiu 11 proc. pasaulio BVP. Prognozuojama, kad iki $2020 \mathrm{~m}$. kelionių padaugès iki 1,6 mlrd. Indijos priekrantès zonos ekosistemos yra jautrios tokiai sparčiai turizmo ir apgyvendinimo plètrai. Siekiant užtikrinti ilgalaikę regiono plètra, kai dèmesys skiriamas ne tik turizmo veikloms, priekrantės zonų turizmo planavimo ir valdymo procesai gali būti patobulinti geriau suvokiant socialines, ekologines sistemas ir jų tarpusavio ryšius. Straipsnyje analizuojama tiek priekrantès zonu darnumas, tiek jų galima talpa, atsižvelgiant $\mathfrak{i}$ ilgalaikius regiono tikslus.
\end{abstract}

